UDC $94 \ll 1960 / 1970 »(574)$

IRSTI 03.20.

https://doi.org/10.51889/2020-1.1728-5461.11

Yedgina G.T. ${ }^{1}$, Zhumashev R.M. ${ }^{2}$, Zuyeva L.I. ${ }^{3}$, Shapagatova D.D. ${ }^{4}$, Yegeshova L.A. ${ }^{5}$

${ }^{1} \mathrm{PhD}$ student of Ye.A. Buketov Karaganda State University, Karaganda, Kazakhstan

${ }^{2}$ Professor of Ye.A. Buketov Karaganda State University, Karaganda, Kazakhstan

${ }^{3}$ Associate professor of Ye.A. Buketov Karaganda State University, Karaganda, Kazakhstan

${ }^{4}$ Teacher of Ye.A. Buketov Karaganda State University, Karaganda, Kazakhstan

${ }^{5}$ Teacher of Ye.A. Buketov Karaganda State University, Karaganda, Kazakhstan

\title{
THE INITIAL PERIOD OF THE LABOR ACTIVITY OF N.A. NAZARBAYEV ON THE PAGES \\ OF THE SOVIET PRESS OF THE 1960s-1970s
}

\section{Abstract}

The labor activity of the First President of the Republic of Kazakhstan Nursultan Abishevich Nazarbayev began in the city of Temirtau in 1960, where he came to the construction of the Kazakhstan Magnitka, the Karaganda Metallurgical Plant. Here he went through a good school from the worker of the department of Domenstroy of the Kazmetallurgstroy trust, the furnaceman of the furnace shop of the Karaganda Metallurgical Plant, to the second secretary of the Karaganda Regional Committee of the Communist Party of Kazakhstan. From the first days his labor activity was brightly reflected on the pages of the press of that period. The authors revealed more than 150 articles in which the name of N.A. Nazarbayev was mentioned. The texts of some of them are given in the article.

Keywords: Republic of Kazakhstan, First President, history, Komsomol, labor activity, Communist, Kazakhstan Magnitka

Г.Т. Едгина ${ }^{1}$ Р.М. Жұмашев ${ }^{2}$, Л.И. Зуева ${ }^{3}$, Д.Д. Шапагатова ${ }^{4}$, Л.А. Егешова ${ }^{5}$

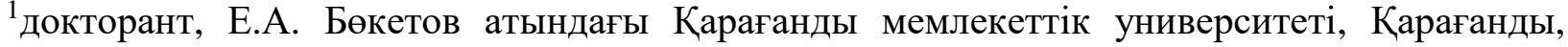
Қазақстан

${ }^{2}$ профессор, Е.А. Бөкетов атындағы Қарағанды мемлекеттік университеті, Қарағанды, Қазақстан

${ }^{3}$ доцент, Е.А. Бөкетов атындағы Қарағанды мемлекеттік университеті, Қарағанды, Қазақстан

${ }_{4}^{4}$ оқытушы, Е.А. Бөкетов атындағы Қарағанды мемлекеттік университеті, Қарағанды, Қазақстан

5 оқытушы, Е.А. Бөкетов атындағы Қарағанды мемлекеттік университеті, Қарағанды, Қазақстан

\section{0-1970 ЖЫЛДАРДАҒЫ СОВЕТТІК БАСПАСӨЗ БЕТТЕРІНДЕГІ Н.Ә. НАЗАРБАЕВТЫН АЛҒАШҚЫ ЕНБЕК ЖЫЛДАРЫНДАҒЫ ӨМІРБАЯНЫ}

Андатпа

Қазақстан Республикасының Алғашқы Президенті Әбішұлы Нұрсұлтан Назарбаевтың еңбек жолы 1960 жылдары Теміртау қаласында, Қазақстанның Қарағандыдағы магниттік металлургиялық комбинат құрлысына келген кезінен басталды. Ол Қарметте құю машинасының шойындысы, домна пешінің горновойы, домна цехының диспечері, 
газшысы болып жұмыс істегені жұмыскерлерді басқарудағы жақсы мектеп болды және Қазақстанның коммунистік партисының Қарағанды облыстық комитетінің екінші хатшы дәрежесіне дейін көтерілді. Сол жылдардағы оның еңбек жолының алғашқы күнінен бастап баспасөз беттерінде жарық көріне бастады. Жазушылардың Н.Ә. Назарбаевтың аты аталған 150-дей мақалалары шығарылды. Мақалада кейбір мәтіндері келтіріледі.

Кілт сөздер: Қазақстан Республикасы, Тұңғыш Президент, тарих, комсомол, еңбек қызметі, коммунист, Қазақстан Магнитка

Едгина Г.Т. ${ }^{1}$ Жумашев Р.М. ${ }^{2}$, Зуева Л.И. ${ }^{3}$, Шапагатова Д.Д. ${ }^{4}$, Егешова Л.А. ${ }^{5}$

${ }^{1}$ докторант, Карагандинский государственный университет им. Е.А. Букетова, Караганда, Казахстан

${ }^{2}$ профессор, Карагандинский государст венный университет им. Е.А. Букетова, Караганда, Казахстан

3 доцент, Карагандинский государственный университет им. Е.А. Букетова, Караганда, Казахстан

${ }^{4}$ преподаватель, Карагандинский государственный университет им. Е.А. Букетова, Караганда, Казахстан

5 преподаватель, Карагандинский государственный университет им. Е.А.Букетова, Караганда, Казахстан

\section{НАЧАЛЬНЫЙ ПЕРИОД ТРУДОВОЙ БИОГРАФИИ Н.А.НАЗАРБАЕВА НА СТРАНИЦАХ СОВЕТСКОЙ ПРЕССЫ В 1960-1970-е гГ.}

\section{Аннотация}

Трудовая деятельность Первого Президента Республики Казахстан Нурсултана Абишевича Назарбаева началась в городе Темиртау в 1960 году, куда он приехал на строительство Казахстанской Магнитки, Карагандинского металлургического комбината. Здесь он прошел хорошую школу от рабочего управления «Доменстрой» треста «Казметаллургстрой», горнового доменного цеха Карагандинского Металлургического комбината до второго секретаря Карагандинского обкома Компартии Казахстана. С первых дней его трудовая деятельность ярко освещалась на страницах прессы того периода. Авторами выявлено более 150 статей, в которых упоминалось имя Н.А Назарбаева. Тексты некоторых из них приводятся в статье.

Ключевые слова: Республика Казахстан, Первый Президент, история, комсомол, трудовая деятельность, коммунист, Казахстанская Магнитка

\section{Introduction}

That was in 1958. An inconspicuous Kazakh guy Nursultan Nazarbayev came to Kazakhstan's Magnitka by the Komsomol ticket. He grew up in a village and graduated from the ten years school there. He never saw blast furnaces in his life. But having heard about the construction of the Karaganda Metallurgical Plant, he flew to Temir-Tau on the wings of a dream . The guy worked a little time at the construction site. Together with a troupe of youth he was sent to Ukraine to learn how to melt metal. With these words, the article by the secretary of the Komsomol organization of the blast furnace shop of the Karaganda metallurgical plant Yesengali Sadykov "The Kazakh is the Ukrainian's brother" in the newspaper "Socialisticheskaya Karaganda" dated June 12, 1962 began [1]. He continued: The metallurgists of the fraternal republic warmly welcomed the envoy of Kazakhstan. They patiently and carefully taught the difficult profession of a furnaceman for blast furnaces. And Nursultan mastered the matter. And in 1960, having returned already to his native city, he gave out the first Kazakhstani cast iron with his own hands. Workmates, the Russian guys, taught Nursultan to speak Russian fluently. And now the aul guy is a student in the evening department of the Polytechnic Institute. He is a shockworker of communist labor, a delegate to the X Congress of the Komsomol of Kazakhstan. 
And at the 10th congress of the Komsomol Nursultan Nazarbayev was elected a candidate member of the Komsomol Central Committee. Wide roads opened in front of a simple Kazakh boy. On this he was helped by a great friendship of working guys like him, the brothers from among the Ukrainians, Russians, Georgians, Latvians.

The furnaceman Karimov Bulat, transporter typewriter Rimma Volokitina, locksmith Ivan Sheleg and many others went through a good school in Magnitogorsk. Friendship helped them become excellent metallurgists.

The guys of our workshop continue to correspond with their friends from Magnitogorsk, Chelyabinsk, Nizhny Tagil, Cherepovets and other cities. They share their experience, talk about how the youth of Kazakhstan's Magnitka live [1].

\section{Methodology and research methods}

When writing the article, the following general scientific methods were used: methods of empirical research, namely, comparisons, descriptions and observations; methods of theoretical knowledge; general logical methods and techniques of research, namely, analysis and synthesis, analogy, system approach. Special historical methods were also used. They are a comparative historical method, a microhistoric approach, since the macrohistorical approach reflects changes in general development of society.

\section{Discussion}

The labor path of N.A. Nazarbayev began in 1960 in the city of Temirtau after studying at the Dneprodzerzhinsk school No 8. N.A. Nazarbayev came to Temirtau specifically for the construction of the Karaganda Metallurgical Plant. In 1960, the first blast furnace was launched, but this significant event was preceded by a rather long and difficult path. In the difficult years of the World War II, the country needed metal, and the Council of People's Commissars of the USSR decided the following: to build a metallurgical plant on the basis of iron ores of the Atasuisk deposit in Kazakhstan. On October 1, 1942, the Council of People's Commissars ordered the People's Commissariat to develop a design assignment for the construction of the Karaganda Metallurgical Plant, and in the summer of 1943 the first design assignment drawn up by Gipromez was approved by the People's Commissar of Ferrous Metallurgy I.F. Tevosyan. These were the very first steps in the development of Kazakhstani metallurgy ...

In February 1956, at the XX Congress of the Communist Party of the Soviet Union in Moscow, the decision was made: "To put into operation two blast furnaces with a capacity of 1 million 350 thousand tons of cast iron per year and a continuous sheet mill at the Karaganda Metallurgical Plant." In May of the same year, the first group of youth went to Temirtau from Almaty, being the capital of Kazakhstan those years. And four years later, on June 30, 1960, the State Commission signed an act on the commissioning of a blast furnace complex No. 1 with a volume of 1,513 cubic meters. On July 3 of the same year, blast furnace No. 1 produced the first Kazakhstani cast iron, this day became the birthday of the Kazakhstan's Magnitka [2].

During this period, the newspapers of Temirtau and Karaganda regularly published articles mentioning the name of Nursultan Nazarbayev. Some articles only mentioned his name, and some spoke in detail about his biography and work career. Due to these articles one can trace all the milestones of his working career in the Karaganda period.

On April 6, 1962 in the newspaper "Socialisticheskaya Karaganda" [3] an article by D. Nikolayev "Nursultan is a working man" was published: In the Central Committee of the Komsomol of Kazakhstan I was shown an ingot of cast iron.

- Our first, Kazakhstan one, said the Komsomol members proudly. - Yes, and its creators have not quite the usual fate. Meet with one of the guys from the metallurgical plant, talk to them, they will tell you a lot.

And here we are talking with the second furnaceman of the blast furnace Nursultan Nazarbayev $\cdots$ 
A boy grew up in a steppe village in the very south of the republic. The life of his grandfather and father was connected with the steppe. Perhaps he could become a good shepherd, or maybe he could sit at the controls of a tractor, or drive a combine along the wheat sea. But the busy, restless life of our time decided the fate of the young steppe guy differently....

... Half-stations and cities sailed outside the window of the railcar. Nursultan got many acquaintances in a few days, more than in all the years of the study in a rural school.

- Who are you and where are you going, - the fellow travelers asked.

The guy took a red book out of his pocket and showed it to everyone.

- To Dneprodzerzhinsk. He will study to be a metallurgist,- people said and shook their heads approvingly.

At the Dzerzhinsky Ukrainian Metallurgical Plant, Kazakh youths were met warmly.

- You will be the replenishment of the working class,- the master Dmitry Izotovich Pogorelov told them. -Are you not afraid of difficulties? Our work is hot, - he said and looked inquiringly at the hushed guys. Nursultan also looked around his comrades and answered for everyone:

- We won't be scared.

The master noticed the smart guy. More than once I thought to myself: "He will make the most of it. He's not afraid of hot things. "And when, after the study, the Kazakh guys were handed the certificates of the eighth category furnacemen, Pogorelov said to Nazarbayev aloud:

- Work as you studied. Soon you will command yourself at the blast furnace.

It was two years ago. The Kazakhstani met the expectations of the Ukrainian metallurgist. He worked in the first blast furnace, helped Boris Vasiliyevich Yagovitov break through the notch.

Working days went on. Hot metal floated through the gutter. The plant grew, the skill of Nursultan was growing stronger. Now he is the second furnaceman. Today, everyone knows about a capable metallurgist. The young man bears the honor of a working man.

On the eve of the opening of the XXII Party Congress, an important event took place in the life of Nursultan: he was accepted as a candidate member of the Soviet Union Communist Party. The young communist began to work even more selflessly, and evidence of this is the well-deserved title of the shockworker of communist labor, which he was awarded at the end of last year [3].

On September 8, 1962, a photo of metallurgists made by S.Chetverikov was published in the? Temirtauskyi rabochyi" newspaper [4] with a short note: Here they are, the creators of cast iron, the domna workers of the Kazakhstan giant, the Karaganda Metallurgical Plant. Three thousandth smelting was completed in the second blast furnace. Hundreds of tons of metal were given out to the Motherland, and now the domna workers are going home.

And tomorrow they will again take their working places at the furnace, and again the seven-year period metal will pour into ladles and molds [4].

In the big article by A.Balabayev, "Years of Growth" in the "Temirtauskyi rabochyi" newspaper [5] dated November 7, 1961, the name of N.A. Nazarbayev was mentioned along with the name of his friend Khamibulla Sarekeyev: two friends deserved the general recognition of their comrades, two furnacemen Nursultan Nazarbayev and Khamibulla Sarekeyev. They both came from the same region, mastered the profession together, traveled together to internships and replenish their knowledge in Ukraine. One small discrepancy is between them, flashing his wet white teeth, tells the first furnaceman. Khamibullah was weaker than his friend. No, not at work both of them are good at it, but still ... It turns out that friends went to study at the evening institute at the same time and passed exams for the first year. But here Khamibullah gave up, it seemed difficult to him, he even rejected the help of his friend... Now they both are worried, and Khamibullah still does not want to admit his mistake. His friend will overtake Khamibullah , then it will be even worse.

Friendship in life and in work is stronger than cast iron.

Here is a small episode, the most ordinary one, and in it, as in focus, the commissure of the collective appeared. Once it happened that two members of the brigade fell ill, one was called to the military enlistment office. There were three people left at the furnace. It was acting up. It was hard to work. But the three remaining, replacing friends, coped with their duties and produced 
cast iron on time, exactly on schedule. The metallurgists of the first furnace confirmed that their strong hands were capable of doing everything. Everything? Oh sure. There is other evidence for this. Domna does not like gapers. it is able to repay insidiously to such people. It happens to be obstinate even when people are ready for its "tricks" [5].

The article by S. Bezzubov "Young people have a road everywhere" in the newspaper "Temirtauskyi rabochyir" dated July 15, 1961 [6] talked about the young metallurgists of the Kazakhstan's Magnitka Petr Shatskikh, Nikolai Mazurkevich, Bulat Dosaliyev, Norsultan Nazarbayev and others: among the young metallurgists of the Kazakhstan Magnitka there are many hardworking young men and women who know their job. Knowledgeable and experienced furnace and gas workers, furnace masters come out of their midst. Komsomol member Petr Shatskikh came to the Magnitka being the third furnaceman. With the commissioning of the second blast furnace complex, he becomes a senior furnaceman with the assigned responsibilities to cope perfectly. By his selfless work, the young metallurgist won the love and respect of the collective. Together with his comrade Kanashkin, Petr Shatskikh were greatly honored to report on behalf of builders and metallurgists to the government of the republic at the anniversary session of the Supreme Council of the Kazakh SSR and personally to the First Secretary of the Central Committee of the Soviet Union Communist Party and Chairman of the Council of Ministers of the USSR Comrade N.S. Khrushchev about the early commissioning of the second blast furnace and present a commemorative tile with the inscription: "Casted of the cast iron of the first smelting of blast furnace No. 2 of the Kazakhstan Magnitka VI-61." Komsomol member Vladimir Andreyev led a team of working bunkers. He prepared Kenes Kulmagambetov to replace himself, and then began to work as gas worker of the first furnace. And there are many such wonderful people who have been nominated for the responsible sections of the first and second blast furnaces! For example, Nikolai Mazurkevich. With the commissioning of the first blast furnace, he worked as a gasman's assistant, then as a gas worker, and now he is replacing the foreman. He knows not only technology but also the process of organizing people. Bulat Dosaliyev proved himself to be a skilled organizer of production. He arrived to the Kazakhstan Magnitka as a gas worker, for the year he mastered the profession of senior gasman. The young specialist went through a good life school. The shop managers noticed his abilities and promoted him to work as the foreman of the second furnace. Dozens of metal melting conducted under his leadership once again confirm the correctness of the decision of the workshop's managers.

Recently, the furnacemen Bulat Karimov, Norsultan Nazarbayev, Tulegen Adam-Yusupov, gutter workers Khamid Zhakizhanov, Shaizat Zhilkaidarov, Askarbek Kleugabylov and many others were nominated to work on the responsible areas of the first and second blast furnaces.

It is gratifying to realize that young national cadresare successfully coping with the tasks in collaboration with the Russians, Ukrainians and Belarusians. In the socialist competition for a worthy meeting of the Day of the Metallurgist, the XI Congress of the Communist Party of Kazakhstan and the upcoming Congress of the Soviet Union Communist Party, the blast furnace team completed the mission of this year June to smelt cast iron by 102.2 percent [6].

In December 1961, N.A. Nazarbayev was awarded the title of the shockworker of communist labor. This fact, of course, was reflected in the press of those years, in the article "The Flight course is the Dawns of Communism" in the newspaper "Temirtauskyi rabochyi" [7] dated December 1, 1961: the gutterman Aleksey Zorin, the driver of the carriage weights Stepan Makukhin, the furnaceman Nursultan Nazarbayev were the first in the team of Vadim Mikhailovich Romanov who entered the correct path, i.e. to work, to study and to live according to communism. They were among the first ones to receive the title of the shockworkers of communist labor. And the one who goes first paves the way for everyone. And so it happened in the brigade of

V.M. Romanov. The team of metallurgists began to go ahead of those who went on the communist road. For the current year they achieved a lot. They began to study political economy, entered technical school and institute to study. And the most important thing is that they consciously and enthusiastically worked. Not so long ago, the blast furnace shop spread the good news: the brigade of Vadim Mikhailovich Romanov was awarded the title 
of the brigade of communist labor. This is the first swallow in the blast furnace shop. The course of its flight is the communist dawns [7].

In the article by the deputy secretary of the party bureau of the Karaganda Metallurgical Plant T. Likhomanov "Blast furnace operators are on watch" in the newspaper "Temirtauskyi rabochyi [5] dated November 7, 1961, the author spoke about the successful work of the first blast furnace team, among which the third furnaceman Nursultan Nazarbayev was mentioned, and about the early fulfillment of socialist obligations by this team: Good things are in the lives of the domna workers of the Karaganda metallurgical plant. They meet the bright and joyful holiday of the Great October Revolution implementing the production program on producing the Kazakhstan cast iron and other high economic indicators. Both blast furnaces work with overfulfillment of the plan. The first task was completed in October by $100.9 \%$, and the second one was done $100.7 \%$. The Homeland received hundreds of tons of overplanned cast iron from the Kazakhstan's Magnitka. People with knowledge of the matter manage the operation of blast furnaces, skillfully maintain the technological regime.

Recently, the second blast furnace named after the XXII Congress of the Soviet Union Communist Party came into operation. But metallurgists are already showing the patterns of highly productive labor. Here are the names of real and skilled fighters for the production of overplanned cast iron: the first furnaceman Boris Yagovitov, the second furnaceman Mansur Abdrakhmanov, the furnaceman assistants Anatoly Tokmanov, Vladimir Puzanov, Alik Serikov, blast furnace loading engineer Yuryi Konnov, electricians' foreman Fedor Proskuryakov, foreman of the bunker overpass Kenes Kulmagambetov.

Shift master, communist Anatoly Glazunov, was an ordinary bricklayer until recently. But he showed his organizational abilities, the ability to mobilize the efforts of the team to carry out any tasks. The management, party bureau of the workshop were not mistaken, having nominated a young specialist for the position of a master. He is not only a good organizer of production, but also an adviser to the team. At their meeting, the Communists elected him the party leader. Party group organizer Anatoly Glazunov boldly leads the domna workers along the path of successfully completing the seven-year assignments.

The team of the first blast furnace named after the 40th anniversary of the Lenin Komsomol is also working successfully. The fourth furnaceman Khamibulla Sarekenov, who can replace any furnaceman at the right time, the third furnaceman Nursultan Nazarbayev, the senior furnaceman Karim Akhmedzyanov, the second furnaceman Dmitry Odegov enjoy labor glory in the workshop.

On the day of the opening of the XXII Congress of the Soviet Union Communist Party, a rally was held in the workshop, speaking at which the domna worker comrade Kovalevskyi reported on the early fulfillment of socialist obligations by the collective members. As a gift to the party congress, hundreds of tons of Kazakhstani cast iron, smelted by the hands of the glorious work team of the domna workers, were given out.

And now, celebrating the forty-fourth anniversary of the Great October Socialist Revolution, the collective of the workshop is eager to fight with renewed vigor to implement the historical Program of the Soviet Union Communist Party, approved at the party congress. The Kazakhstan's Magnitka domna workers live and work with the following thoughts: always to be in the ranks of the leading fighters for the seven-year plan for building communism [5].

In 1962, the youth of Temirtau elected Nursultan Nazarbayev as their representative at the X Congress of the Komsomol of Kazakhstan, and then - the representative at the XIV Congress of the Komsomol. In Moscow, the envoys of republican youth organizations met with thousands of their peers and photographed together for memory. Then they took part in the World Festival of Youth and Students, held in the capital of Finland, Helsinki. The festival program was very eventful: meetings, sessions, debates. On August 18, 1962, the newspaper "Temirtauskyi rabochyi" [8] published an article "10 Days in Helsinki", in which N. Nazarbayev talked about his impressions after a trip to the youth festival: every Friday in the youth cafe "Dream" the city's Komsomol members hold theme evenings. In a relaxed atmosphere, they argue about the 
best, more rational use of free time, express their opinion about the films, take interest in the future of our city.

Last Friday, young men and women of the Karaganda Metallurgical Plant gathered to listen to the participant of the VIII World Festival of Youth and Students the furnaceman Nursultan Nazyrbayev.

- In spring, when they told me to prepare for a trip to the festival, I must admit that I did not believe it,- Nursultan began his story. But the closer the appointed day came, the more excited I was. Finally, I am on the IL-18 airplane, the direction is Moscow. The country sends me to the festival. In Moscow, he met with other envoys of Kazakhstan. Among them were a shepherd from the Pavlodar region Zhangazin, a deputy of the Supreme Council, a milkmaid of the AlmaAta region, Tergeuova and others.

On July 24, the Moscow-Helsinki train took 120 people to Suomi country, the country of lakes and forests, so that they could tell their firm "No!" to the war at the World Youth Forum, in the interweaving of the fraternal hands of the peers of all countries.

It's hard to put into words the way we were met in Helsinki. It needs to be seen and felt. Finnish Komsomol members and old communists came to the station with huge bouquets of flowers (I must say that in Finland there are a lot of them), and with them there were delegations from other countries, from China, Czechoslovakia, Hungary and others. And the first thing that united us was the song "Anthem of Democratic Youth". Everybody sang it, the funny Swedish song "Hey Rulate" turned out to be popular. There were friendly smiles, handshakes, kisses. But in the midst of a warm, friendly atmosphere, there sometimes were threatening physiognomies of the antifestival persons stuffed with Bonn propaganda, appearing from behind the backs of the hosts. But they were in a minority and they could not spoil the meeting.

We arrived earlier than the main delegation to arrange the Sputnik club and set up the tents. But despite this, we had some free time. The day after arrival, we visited the sights of Helsinki, and then went to the city of Turkin, the former capital of Finland. Komsomol members and youth of the city gave us a warm welcome. They organized a concert for us. We also immediately assembled the choir, among us there were soloists, dancers, masters of the word. After that there was a waltz of friendship and songs, songs, songs ... Exchange of memorable badges and gifts. Boys and girls of Finland told us how they live. Listening to them, I thought that the happiest people in the world are the Soviet people. We do not have unemployment, everyone has open doors to science: do it, go for it! I knew about their life before, but only from books and newspapers, and here I had to face the reality, to see firsthand what capitalism was and how difficult life was for ordinary people. The roads to education and science are closed to them. In order to study, they need to have a lot of money. And the annual income of a worker is many times less than the tuition fee. Medical care is at a very low level. There is one doctor per 1000 people.

On July 28 we met the "Georgia" ship. It delivered the rest of our delegation. This meeting took place far in the open sea. Thousands of boats, filled with people, surrounded "Georgia", chanting "Peace, friendship" in different languages. All the inhabitants of Helsinki and the envoys of the countries gathered on the pier, meeting the Soviet delegation. And here our artists gave a wonderful concert, it lasted more than three hours. Smiles bloomed on the faces of black, white, and yellow people without fading. And I saw tears of joy in the eyes of the old communists of Finland.

It is hard to put into words the first day of the festival. We walked in columns to the Olympic stadium. It was raining cats and dogs. But no one paid attention to it. It should be noted that the reactionary-minded bourgeoisie looked at the procession of youth with displeasure, and they were especially haunted by our delegation.

It is difficult to tell in detail what happened at the festival. I met many of my peers from different countries. The young Spaniard had to overcome thousands of obstacles to get to the festival. He came to tell people around the world that Spain was shrouded in a network of military bases, that active preparations for war were going on in the territory of his homeland, to talk about those 
who pulled Spain into that, stating that all progressive Spaniards, along with peace supporters, would uphold it to the end. I had to meet with American boys and girls as well. They publicly stated that they did not intervene in politics: "we are for peace, but let others fight for it,"- they said. Obviously, when they were sent to the festival, they were strictly ordered not to talk about politics and about everything that worried young people around the world. I came face to face with those who were propagandizing war.

Festival participants talked about how young people lived, how they fought for peace and friendship, against colonialism. Japanese delegates talked about the horrors of nuclear war. Discussions were held on political topics. At one of those discussions at the Friendship Club, there was a talk about general and complete disarmament. All speakers pointed the fact that America ruled the entire militant world that only due to American rulers it would be hard to get rid of colonialism, there was an active preparation for war.

An excellent rebuke was received by American students at that debate. The youth gathered unanimously spoke out, listed all the misconduct of the American rulers.

Concerts, meetings and disputes were held at all venues and in clubs. And there was a sea of smiles and friendly words around. The Russian, Chinese, Malay, Finn, Pole, Cuban, people of different nationalities and views found common ground when it was discussion on friendship and peace.

Ten days of the festival will forever remain in my memory, as a great unity of the people of all countries in the fight against the instigators of war [8].

\section{Conclusion}

Thus, we can state the fact that the activity of N.A. Nazarbayev even at the very beginning of his career was widely reflected on the pages of Soviet newspapers. The following newspapers were among them: Kazakhstanskaya Pravda, Komsomolets Karagandy, Socialisticheskaya Karaganda, Industrialnaya Karaganda, Temirtauskyi rabochyi, Metallurg, Metallurg Temir-Tau, Ortalyq Qazaqstan.

\section{Recommendations}

Labor and political activity of N.A. Nazarbayev in the Karaganda region in the 1960s-1970s was not the subject of a special study. Modern Kazakhstani historical science lacks comprehensive and generalizing studies examining various aspects of this problem. Nevertheless, it demands further study.

References:

1 Социалистическая Караганда. - 1962. - 12 июня

2 Сайт акимата Карагандинской области [Электронный ресурс]. - Режим доступа: https://karaganda-region.gov.kz/ru/magnitka 50-1-113.

3 Социалистическая Караганда. - 1962. - 6 апреля

4 Темиртауский рабочий. - 1962. - 8 сентября

5 Темиртауский рабочий. - 1961. - 7 ноября

6 Темиртауский рабочий. - 1961. - 15 июля

7 Темиртауский рабочий. - 1961. - 1 декабря

8 Темиртауский рабочий. - 1962. - 18 августа

Пайдаланылған әдебиеттер тізімі:

1 Социалистік Қарағанды. - 1962. - 12 маусым

2 Қарағанды облысы әкімдігінің сайты [Электрондық ресурс]. - Кіру режимі: https://karaganda-region.gov.kz/ru/magnitka 50-1-113.

3 Социалистік Қарағанды. - 1962. - 6 сәуір 
4 Теміртау жұмысшысы. - 1962. - 8 қыркүйек

5 Теміртау жұмысшысы. - 1961. - 7 қараша

6 Теміртау жұмысшысы. - 1961. - 15 шілде

7 Теміртау жұмысшысы. - 1961. - 1 желтоқсан

8 Теміртау жұмысшысы. - 1962. - 18 тамыз 